\title{
Comparative morphology of the larvae of the palm weevils Dynamis borassi (Fabricius) and Rhynchophorus palmarum (Linnaeus) (Curculionidae: Dryophthorinae): Two major pests of peach palms in the Neotropics
}

\author{
Aymer Andrés Vásquez-Ordóñez ${ }^{1}$; Bernhhard Leo Löhr ${ }^{2}$ \& Adriana Elena Marvaldi ${ }^{3}$ \\ 1 Universidad del Valle (UNIVALLE), Departamento de Biología, Sección de Entomología. Cali, Valle del Cauca, Colombia. \\ ORCID: http://orcid.org/0000-0002-4970-9067. E-mail: ayanvaor@gmail.com \\ ${ }^{2}$ Corporación Colombiana de Investigación Agropecuaria (AGROSAVIA), Centro de Investigación Palmira. Palmira, Valle del Cauca, Colombia. \\ ORCID: http://orcid.org/0000-0003-4300-2551. E-mail: blohr@agrosavia.co \\ ${ }^{3}$ Consejo Nacional de Investigaciones Científicas y Técnicas (CONICET), Universidad Nacional de La Plata, Facultad de Ciencias Naturales y \\ Museo, Division Entomologia. Buenos Aires, Argentina. \\ ORCID: http://orcid.org/0000-0001-6029-4803. E-mail: marvaldi@fcnym.unlp.edu.ar (corresponding author)
}

\begin{abstract}
The morphology of the larvae of Dynamis borassi (Fabricius) and Rhynchophorus palmarum (Linnaeus) was compared, described and illustrated. A complete definition of subtribe Rhynchophorina at the larval stage was elaborated, based on mature and submature larvae, and characters of the first instar larvae are provided for the first time. Diagnostic characters to distinguish the larvae of $D$. borassi and $R$. palmarum are mainly from the epipharynx and maxillae, but the abdominal terminal plate also provides differential features that can aid in the identification. The characterization of both species at the larval stage is expected to be useful in the implementation of new control strategies in palm plantations in South America. For practical reasons, a comparative table is appended in Spanish to serve as a quick diagnostic guide for species identification.
\end{abstract}

Key-Words. Coleoptera; Palm weevils; Larval morphology; Bactris gasipaes; Neotropical Region.

\section{INTRODUCTION}

The weevils Dynamis borassi (Fabricius, 1801) and Rhynchophorus palmarum (Linnaeus, 1758) attack native, ornamental and commercially cultivated palms in tropical America (Couturier et al., 2000; Löhr et al., 2015), with significant economic impacts. Dynamis borassi has generated losses of up to $57 \%$ in experimental cultures of the palm Oenocarpus mapora Karst (Couturier et al., 2000). Meanwhile, for $R$. palmarum, its effect as a vector of the nematode Bursaphelenchus cocophilus (Cobb, 1919) on oil and coconut palms has been widely documented, having caused the elimination of large-scale production areas such as Tumaco Bay in Colombia (Löhr et al., 2015).

A similar situation has developed over the last decade in the production areas of peach palm, Bactris gasipaes Kunth (locally known as "chontaduro"), in Colombia. There has been a production loss of 48\% (Agronet, 2016), attributable to the attacks of both $D$. borassi and $R$. palmarum
(ICA, 2015; Pardo-Locarno et al., 2016). Although the presence of $D$. borassi has been documented, current management plans are designed exclusively to control $R$. palmarum (ICA, 2015). Consequently, peach palm production in most of the Pacific lowlands of Colombia has come to a stand-still (A.A. Vásquez-Ordóñez, unpublished). There is ample evidence now that the attack on the peach palm is initiated by $D$. borassi, and R. palmarum only comes in as an opportunist pest (A.A. Vásquez-Ordóñez, unpublished). This may be due to the difficulty to distinguish the larvae of both species, indispensable to determine the role of each species.

A key step in palm weevil research is to develop identification tools that allow field researchers to distinguish the larvae of these species since it is at this stage that major damage is caused. Morphological descriptions of the larvae of D. borassi and $R$. palmarum were made and illustrated by Wattanapongsiri (1966), in addition to those by Cotton (1924) and Anderson (1948). These authors 
recognize the high structural similarity of both species at the larval stage, highlighting the value of some mouthpart structures for differentiation. However, these larval descriptions differ in the terminology used and problems often arise when doing the identifications. Furthermore, details of body chaetotaxy and other taxonomic characters, widely documented in other weevils, are missing or poorly documented. Recently, Chamorro (2019) provided a synoptic key to larvae of genera of Dryophthorinae, based mainly on characters of the mouthparts. The key includes both genera, but information on Dynamis is rather incomplete as no material was available for examination, with only a few characters extracted from existing literature. Therefore, a comparative morphological study of the larvae of $D$. borassi and $R$. palmarum, using standardized terminology is urgently needed to facilitate accurate identification of both species at the larval stage. This is fundamental to document the occurrence and role of $D$. borassi in the recent wide-spread mortality of peach palms in Colombia. It is expected that the new morphological tools will facilitate rapid phytosanitary diagnoses in the field, since rearing larvae to the adult stage can take up to six months (Wattanapongsiri, 1966; Cuellar Palacios, 2019), making the monitoring and control processes too lengthy.

\section{MATERIAL AND METHODS}

We studied 23 larvae, 12 belonging to $D$. borassi and 11 to R. palmarum. All larvae of D. borassi were obtained from adults collected in pheromone traps (ferrugineol) from peach palm plantations in Colombia. The progenitors of five mature and four submature larvae were collected at Tadó, Chocó $\left(05^{\circ} 17^{\prime} 08.82^{\prime \prime} \mathrm{N}\right.$, $76^{\circ} 29^{\prime} 16.34^{\prime \prime} \mathrm{W}$ ) in March 2016. Two first instar and one second instar larvae were produced by females collected in Zabaletas and Bajo Calima, Buenaventura, Valle del Cauca $\left(03^{\circ} 59^{\prime} 00.05^{\prime \prime} \mathrm{N}, 76^{\circ} 58^{\prime} 49.77^{\prime \prime} \mathrm{W}\right.$; 034ㄴ $47.69^{\prime \prime} \mathrm{N}$, $76^{\circ} 57^{\prime} 49.69^{\prime \prime} \mathrm{W}$, respectively) in September 2017. The larvae were reared on artificial diet following the protocol described by Löhr (2016), in the entomology laboratory of the Colombian Corporation of Agricultural Research (AGROSAVIA), Palmira Research Center, Valle del Cauca, Colombia. On the other hand, a mature larva of $R$. palmarum was collected inside the stem of a peach palm at Pueblo Rico, Santa Cecilia $\left(05^{\circ} 20^{\prime} 10.72^{\prime \prime} \mathrm{N}\right.$, $\left.76^{\circ} 08^{\prime 2} 23.06^{\prime \prime} \mathrm{W}\right)$, in November 28, 2017. One first instar, four submature and five mature larvae of $R$. palmarum were reared from adults collected in pheromone traps at Palmira Research Center.

The taxonomic identity of the larval specimens and of their associated adults was corroborated with the keys of Wattanapongsiri (1966), Giblin-Davis et al. (2013) and Chamorro (2019).

The observations, photographs and illustrations for the morphological descriptions were done using the following equipment: Canon EOS 6D Mk ii camera with EF100 mm f/2.8 lens associated with a light box; Nikon DS-Ri1 U3 and JVC KY-F75U cameras, associated with a
Nikon SMZ-1500 and a Leica MZ16f stereo microscopes, respectively. Subsequently, the larvae were dissected and prepared on microscopic slides as in May (1994) and Marvaldi (1999). Finally, the structural characters were documented and illustrated with a Leitz Laborlux S compound microscope and a Nikon SMZ800 stereomicroscope, using their attached drawing tubes. The terminology followed for body parts and setae of the larva of Curculionidae is explained in Marvaldi (1999), May (1994) and Oberprieler et al. (2014). Most larval specimens studied were deposited in the Entomology collection of Museum of La Plata, Buenos Aires, Argentina (MLP). The mature larvae of $D$. borassi, one first instar larva of R. palmarum, and adult specimens of both species were deposited in the Entomology Museum of the Universidad del Valle (MUSENUV), Cali, Valle del Cauca, Colombia.

\section{RESULTS}

The morphology of the larvae of Dynamis borassi and Rhynchophorus palmarum was compared, described and illustrated. A complete larval re-description was elaborated, based on mature and submature larvae, and a characterization of the first instar larva is newly provided. For D. borassi and R. palmarum, the diagnostic larval characters that distinguish them are given.

\section{Subtribe Rhynchophorina \\ (Figs. 1-9)}

The following description applies to mature (and submature) larvae of both Dynamis borassi and Rhynchophorus palmarum, which are, respectively, the type species of the genera Dynamis and Rhynchophorus. It is descriptive of the larval stage of the subtribe Rhynchophorina of the current classification of dryophthorines (see Anderson \& Marvaldi, 2014).

\section{Mature larva (Figs. 1-7)}

Body (Figs. 1A-F) very robust, expanded at middle of abdomen between segments III and VI, narrowing posteriad, with abdominal segments VIII and IX forming a depressed terminal disc (Figs. 6B, 7A-B). Thoracic and abdominal segments with sternellum present (Figs. 1B, E, 6A). Cuticle (Fig. 6) sclerotized around setal groups, elsewhere with coarsely distributed asperities like small spicules; vestiture consisting of sparsely-distributed red-brown setae, mostly short or minute, except longer on terminal disc.

Head (Figs. 2A-B) exposed, longer than wide, strongly sclerotized and deeply pigmented, with paler paramedian stripes. Cervix without typical postoccipital condyles, its dorsal side often thickened and with a pair of cervical sclerites on the membrane at joint of head and prothorax (Fig. 2C). Frontal lines distinct, reaching antennae; frons with two medial longitudinal grooves. Endocarina absent. Antennae in oblique position on anterior margin 


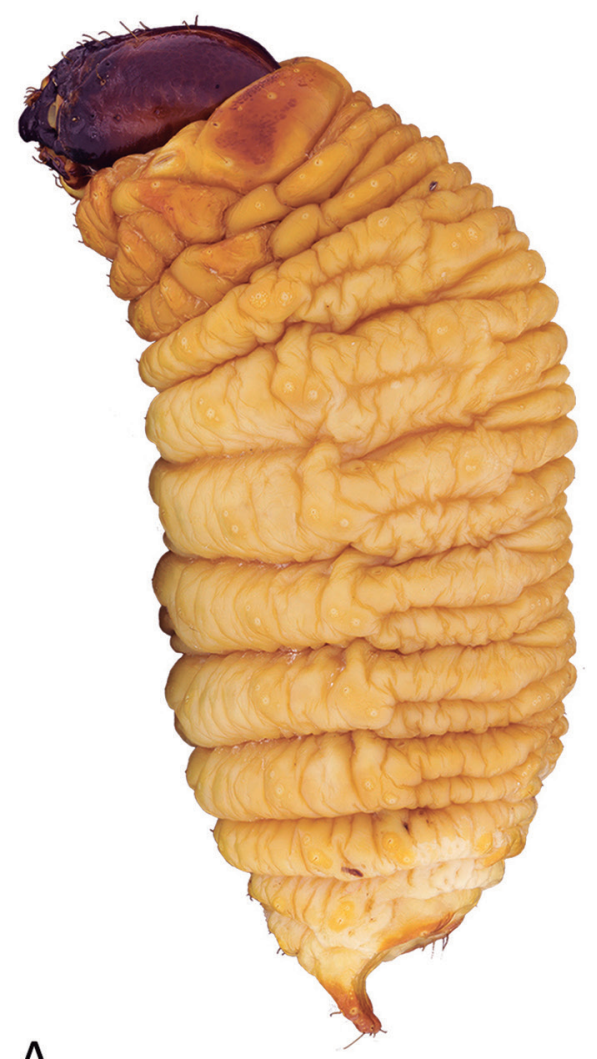

A
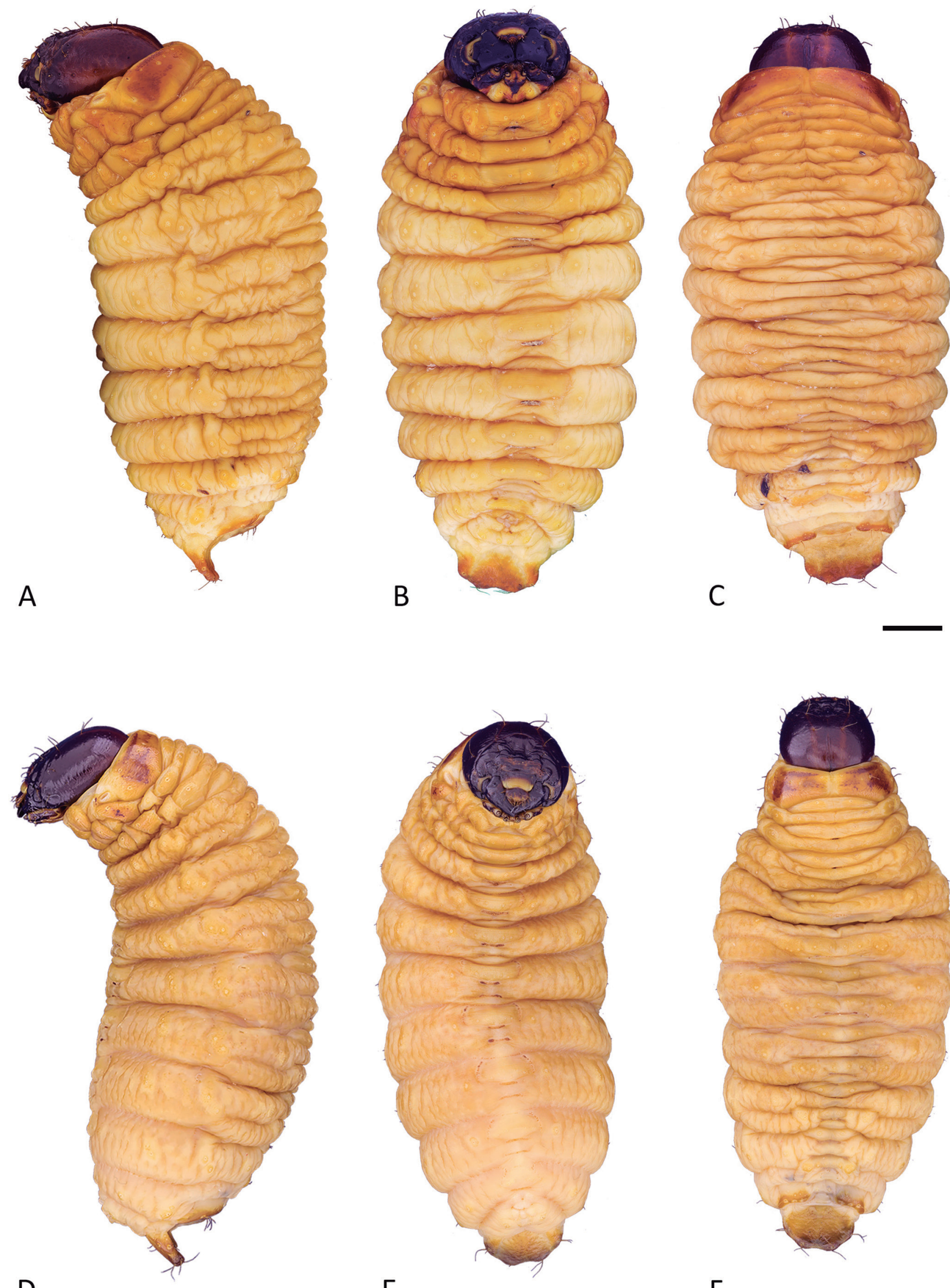

$\mathrm{E}$

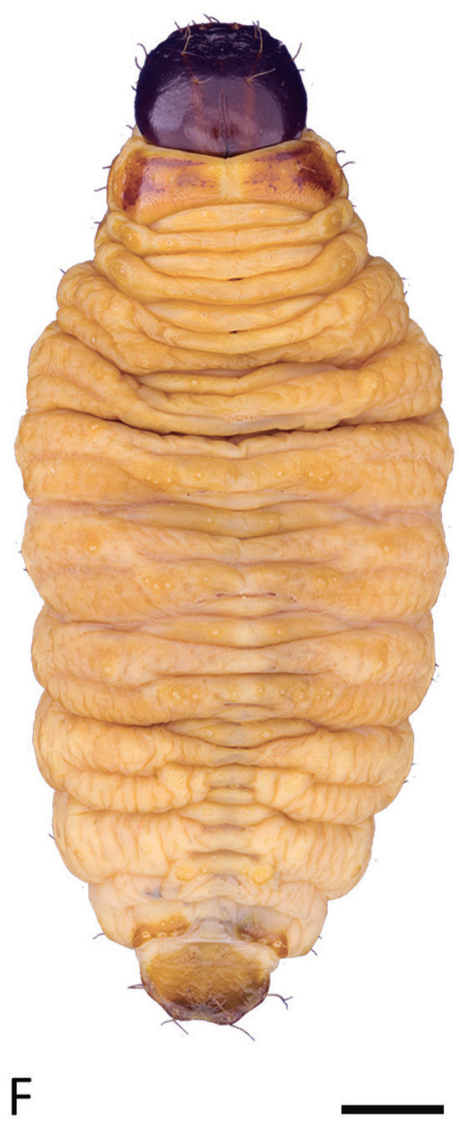

Figure 1. Habitus of mature larva (lateral, ventral, dorsal). (A-C) Dynamis borassi (Fabricius); (D-F) Rhynchophorus palmarum (Linnaeus). Scale bars: 5 mm. 
of head; sensorium longer than wide, subconical, circular in apical view (Fig. 2D). Stemmata present, anterior one distinct, near antenna, posterior one faint in older larvae. Five dorsal epicranial setae (des) present; des 1, des3 and des 5 longest, des 2 short and des 4 minute; des 3 on epicranium, close to frontal line; five frontal setae $(f s), f s 3$ and $f s 5$ longest, $f_{s} 4$ short to well developed, $f_{s} 1$ and $f_{s} 2$ minute; four minute posterior epicranial setae (pes); two lateral epicranial setae (les) unequal in size, les 1 much smaller; ventral cranial setae ( $v c s$ ) unconspicuos. Hypopharyngeal bracon clear. Clypeus (Fig. 3A) with two setae, unequal in size ( $c / s 1$ much larger than $c / s 2$ ), and one sensillum between cls on each side. Labrum (Fig. 3A) pigmented, with anterior margin truncate or slightly produced at middle; labrum with three pairs of setae (Ims), with a pair of basal sensilla, and a pair of anterior sensilla, the latter situated near Ims2. Epipharynx (Figs. 3B-C, 4A-B) with simple setae, with five to more anterolateral setae $(a / s)$; bearing patches of dense pubescence medially and laterally; epipharyngeal sensillum clusters present, a distal pair of three sensillae each, between labral rods, and a proximal pair of two sensillae each; labrum-epipharynx with labral rods elongate, slightly sinuate, joined posteriorly. Mandibles (Figs. 4C-J) robust, dark, often bidentate at apex, with median tooth and a molar area on inner side; with basal sensillum and two short setae on outer surface ( $m d s 1,2)$ placed in pits, aligned longitudinally. Maxillae (Figs. 5A-I) with mala truncate and slightly excised apically, bearing several dorsal setae (dms) aligned in a row medially and irregularly placed proximally (Figs. 5E-F); some $d m s$ branched, mostly bifid; ventral malar setae (vms) simple (Fig. 5H); maxillary palpi 2-segmented, basal palpomere with two sensilla and one minute seta (Fig. 5I). Labium (Figs. 5A-D) with palpi 2-segmented; premental sclerite trident shaped; postmentum sclerotized and pigmented in mesal and lateral areas, with a lighter stripe between them; three postmental setae (pms), proximal pair (pms 1) closer together than pms 2 and pms3, median pair (pms2) the longest; hypopharynx (Figs. 5C-D) densely setose in lateral areas, medially smooth with a longitudinal furrow.

Thorax (Fig. 6A). Pronotum (Figs. 6A, 1C, F) well pigmented, consisting of two sclerotized halves separated

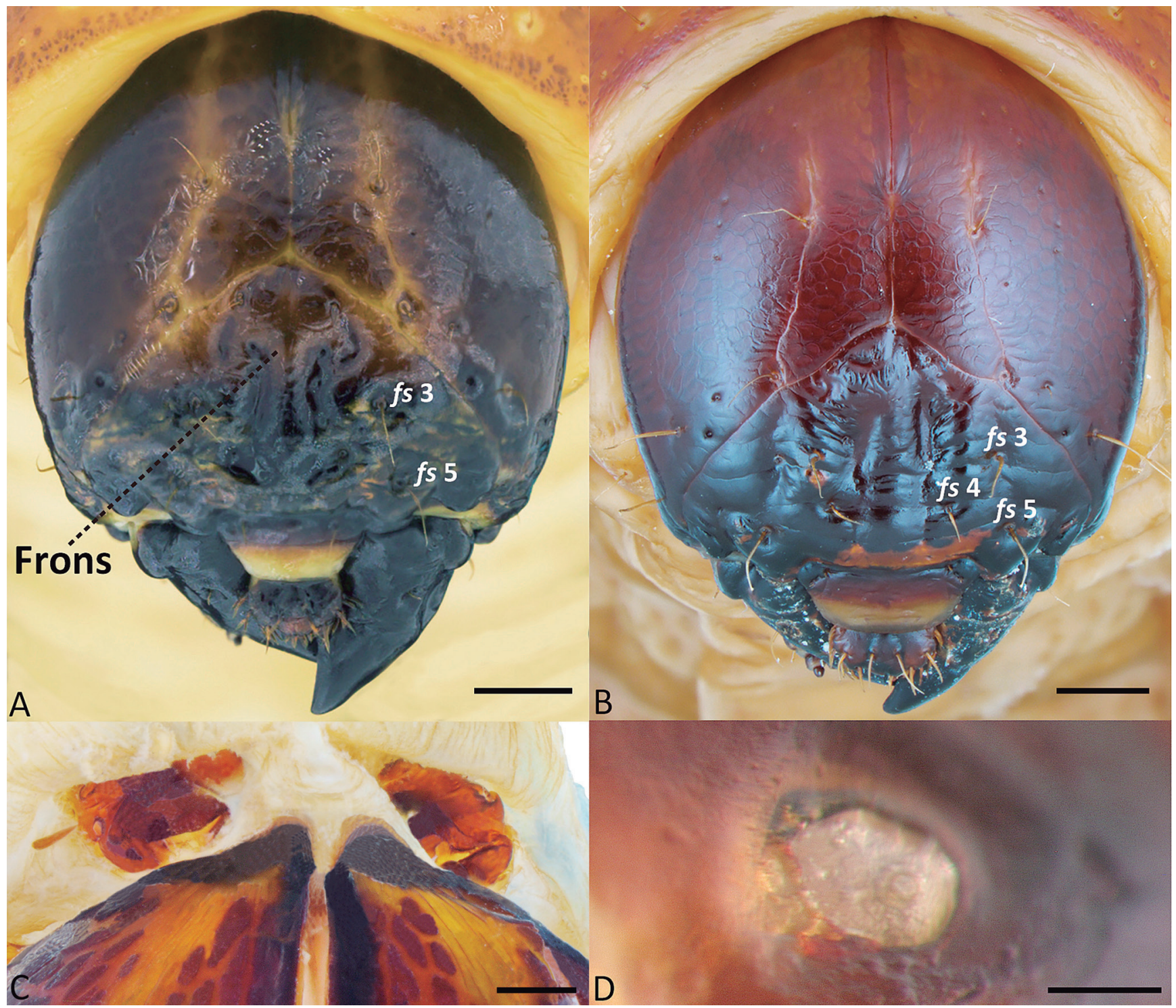

Figure 2. Head of larva, anterodorsal: (A) Dynamis borassi (Fabricius); (B) Rhynchophorus palmarum (Linnaeus). (C) D. borassi, postoccipital membrane showing cervical sclerites; (D) R. palmarum, antenna, apical. Scale bars: $A$ and $B=2 \mathrm{~mm}, C=0.4 \mathrm{~mm}, D=0.1 \mathrm{~mm}$. 
dorsally by a lighter band, bearing few pronotal setae (five to seven). Prothoracic sternum with a median depression (Figs. 1B, E). Meso- and metathorax (Fig. 6A) with one seta on alar area and several very short spiracular setae (ss); epi- and pleural areas subdivided into two lobes. Pedal areas with six setae, one of them minute, close to the longest one. Thoracic spiracles (Figs. 6A, 7C, F-G) placed on prothorax, narrow-ovate, without airtubes.

Abdomen (Fig. 6). Typical abdominal segments (Figs. 1, 6A) with four dorsal folds, bearing five postdorsal setae ( $p d s)$. Segments VIII and IX (Figs. 1, 6B) with fewer but longer dorsal setae, forming a sclerotized dorsal disc, with posterior margin extended into two pairs of broadly defined, seta-bearing lobes (Figs. 6B, 7A-B). Epi- and pleural areas subdivided into three lobes (Figs. 1, 6A). Anal region (Fig. 6B) ventral, anus transverse, four anal lobes, the lateral ones bearing one or two small setae. Spiracles narrow-ovate, without airtubes (Figs. 6A-B, 7D-E, I-J); abdominal spiracles I to VII (Figs. 6A, 7D-E) placed laterally near anterior margin of segments, much smaller than the VIII, but functional; spiracles of segment VIII (Figs. 6B, 7I-J) well developed and placed on dorsum, aligned longitudinally.

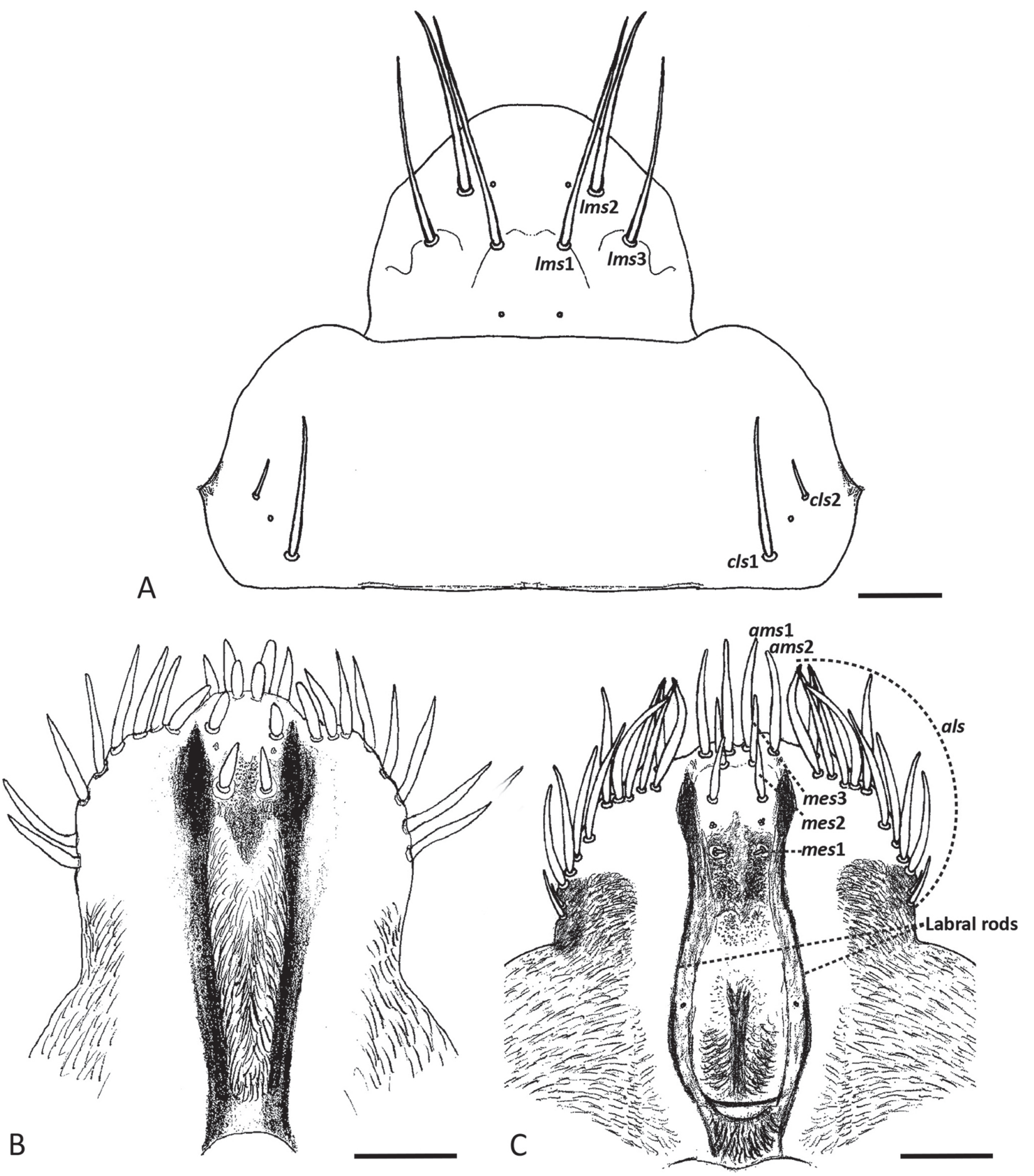

Figure 3. Larval mouthparts. (A) Rhynchophorus palmarum (Linnaeus), clypeus and labrum; (B) Dynamis borassi (Fabricius), epipharynx; (C) R. palmarum, epipharynx. Scale bars: $0.5 \mathrm{~mm}$. 


\section{First instar larva (Figs. 8A-F, 9A-C)}

Both anterior and posterior stemmata distinct, as dark pigmented spots, anterior larger than posterior (Fig. 8C). Egg-bursters (Fig. 8D) present on abdominal segments IV to VII, on either side in the dorso-lateral region of each segment, the posterior pair smaller than those in AIV-AVI; each egg burster (Fig. 8E) arising on a convex tubercle and consisting of a sub-conical, forwardly directed spine, situated anterior to a blunt seta. Only the spiracles of

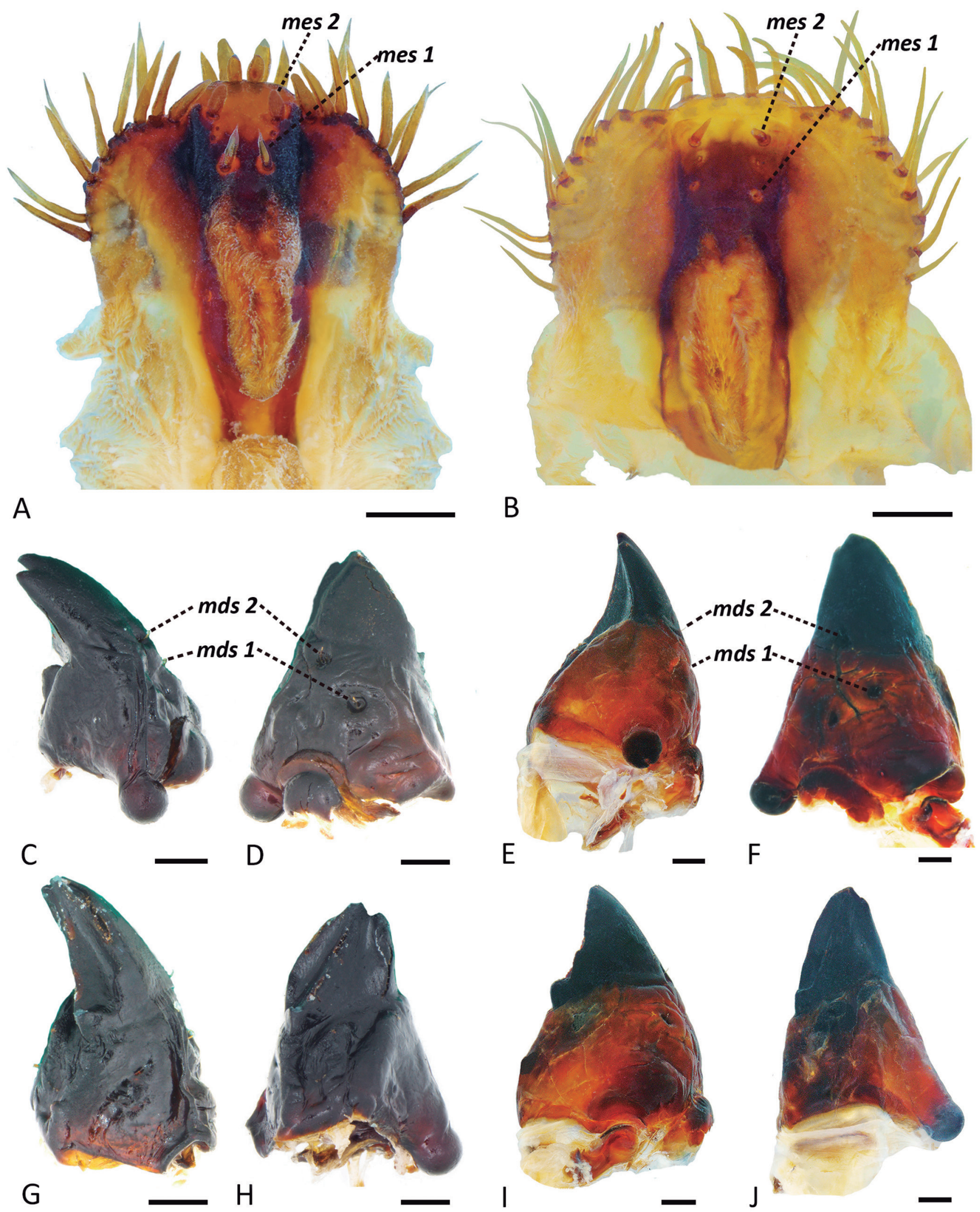

Figure 4. Larval mouthparts. Dynamis borassi (Fabricius): (A) epipharynx; (C-D, G-H) mandible in dorsal, outer, ventral and inner views. Rhynchophorus palmarum (Linnaeus): (B) epipharynx; (E-F, I-J) mandible in dorsal, outer, ventral and inner views. Scale bars: $0.5 \mathrm{~mm}$. 
thorax and abdominal segment VIII (Fig. 8F) are distinct, abdominal spiracles I to VII absent. Abdominal terminal plate (Fig. 8F) with margins only weakly sinuated.

Comments: The characters mentioned above are exclusive of the first instar. Additional differences between early and older instar larvae involve relative dimension of structures, like the antennae, which are relatively much larger in the first instar; the pigmentation and level of sclerotization of body areas tend to increase in successive instars; the differences in length between se- tae of body areas are higher in early instars; when setae are supernumerary (compared to modal numbers), such as those placed laterally in the epipharynx or dorsally in the maxillary mala, their amount is higher in later instars.

\section{Dynamis borassi (Fabricius, 1801)}

Mature larva: Figs. 1A-C, 2A, C, 3B, 4A, C-D, G-H, 5A, C, E, 7A, 7C-E, G-I.
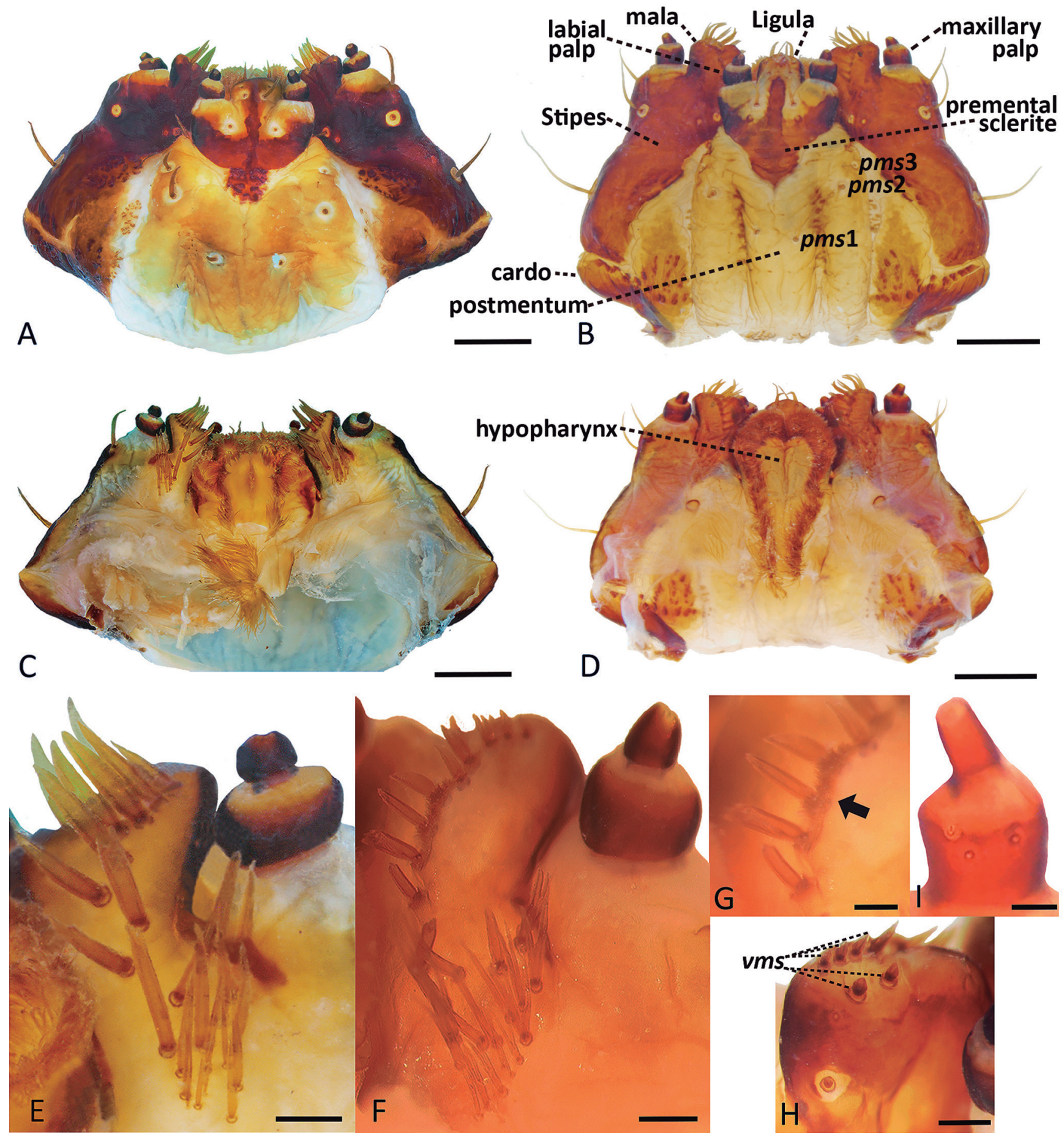

Figure 5. Maxillae and labium of larva. Dynamis borassi (Fabricius): (A) ventral; (C) dorsal; (E) detail of mala, dorsal. Rhynchophorus palmarum (Linnaeus): (B) ventral; (D) dorsal; (F) detail of mala, dorsal; (G) detail of dorsal malar setae; (H) detail of ventral malar setae; (I) detail of maxillary palp. Scale bars: A-D = 1 mm, $\mathrm{E}$ and $\mathrm{F}=0.2 \mathrm{~mm}, \mathrm{G}$ and $\mathrm{I}=0.1 \mathrm{~mm}, \mathrm{H}=0.2 \mathrm{~mm}$. 
First instar larva: Figs. 8A, C-F, 9A-C.

Maximum dimensions: $52.9 \times 23.6 \mathrm{~mm}$, head width $10.5 \mathrm{~mm}$. Chaetotaxy (see Table 1).

Frons (Figs. 2A, 8C, 9A) with two setae well developed ( $f s 3$ and $f s 5), f s 4$ minute (earlier instars) or short. Epipharynx (Figs. 3B, 4A): five (earlier instars) to eight anterolateral setae $(\mathrm{als})$ on each side, none placed proximally near the limit with clypeus; median epipahryngeal setae 2 (mes2) thick, more widely separated than mes 1 , the latter smaller but well developed, distinct; mesal area of epipharynx (between labral rods) with asperities evenly distributed, not leaving a glabrous area; labral rods V-shaped, less widely separated towards their proximal junction than between their distal tips. Maxillae (Figs. 5A, C, E): with dorsal malar setae (dms) without pubescence at their bases; number of $d m s$ about 20 (earlier
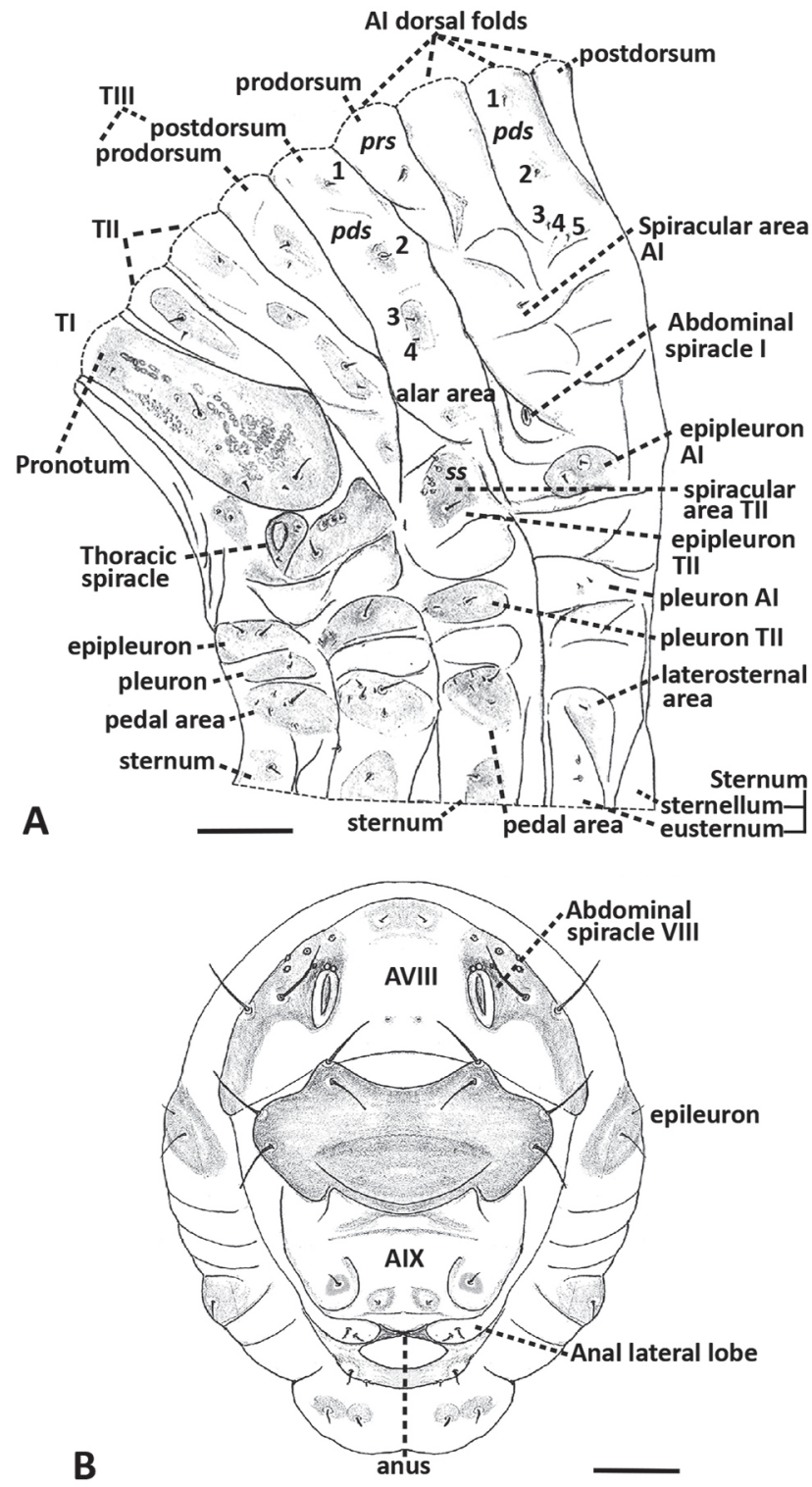

Figure 6. Chaetotaxy of thorax and abdomen, mature larva, Rhynchophorus palmarum (Linnaeus). (A) Prothorax, mesothorax, metathorax and abdominal segment I. (B) Abdominal apex, segments VIII to X, caudal. Scale bars: $A=3 \mathrm{~mm}, B=2 \mathrm{~mm}$.
Table 1. Larvae of Dynamis borassi (Db) and Rhynchophorus palmarum (Rp): Body areas and chaetotaxy; modal numbers of setae of Curculionidae, $D$. borassi and $R$. palmarum ( $\mathrm{V}=$ variable). Terms and abbreviations follow Marvaldi (1999) (see also May, 1994; Oberprieler et al., 2014).

\begin{tabular}{|c|c|c|c|c|c|c|}
\hline \multirow{2}{*}{\multicolumn{2}{|c|}{ Body area }} & \multicolumn{3}{|c|}{ Setal numbers } & \multirow{2}{*}{$\begin{array}{c}\text { Abbrevi- } \\
\text { ations }\end{array}$} & \multirow{2}{*}{ Meanings } \\
\hline & & Modal & $\mathrm{Db}$ & $\mathrm{Rp}$ & & \\
\hline \multicolumn{7}{|l|}{ Head } \\
\hline \multicolumn{2}{|l|}{ frontal } & 5 & 5 & 5 & fs & Frontal setae \\
\hline \multicolumn{2}{|l|}{ dorsal } & 5 & 5 & 5 & des & Dorsal epicranial setae \\
\hline \multicolumn{2}{|l|}{ posterior } & 4 & 4 & 4 & pes & Posterior epicranial setae \\
\hline \multicolumn{2}{|l|}{ lateral } & 2 & 2 & 2 & les & Lateral epicranial setae \\
\hline \multicolumn{2}{|l|}{ ventral } & 2 & 1 & 0 & vCS & Ventral cranial setae \\
\hline \multicolumn{2}{|l|}{ Clypeus } & 2 & 2 & 2 & $c l s$ & Clypeal setae \\
\hline \multicolumn{2}{|l|}{ Labrum } & 3 & 3 & 3 & Ims & Labral setae \\
\hline \multicolumn{7}{|l|}{ Epipharynx } \\
\hline \multicolumn{2}{|l|}{\begin{tabular}{|l|} 
anterolateral \\
\end{tabular}} & 3 & $5-8$ & $10-14$ & als & Anterolateral setae \\
\hline \multicolumn{2}{|l|}{ anteromedian } & 2 & 2 & 2 & ams & Anteromedian setae \\
\hline \multicolumn{2}{|l|}{ median } & 3 & 3 & 3 & mes & Median epipharyngeal setae \\
\hline \multicolumn{2}{|l|}{ Mandible } & 2 & 2 & 2 & $m d s$ & Mandibular setae \\
\hline Maxillae & & & & & & \\
\hline dorsal mala & & V & $\sim 20$ & $\sim 30$ & $d m s$ & Dorsal malar setae \\
\hline ventral mala & & $4-5$ & 5 & 5 & vms & Ventral malar setae \\
\hline palp & & 1 & 1 & 1 & & \\
\hline stipes & & 4 & 4 & 4 & stps & Stipital setae \\
\hline Labium & & & & & & \\
\hline \begin{tabular}{|l|} 
prementum \\
\end{tabular} & & 1 & 1 & 1 & prms & Premental setae \\
\hline & ligula & 2 & 2 & 2 & lgs & Ligular setae \\
\hline postmentum & & 3 & 3 & 3 & pms & Postmental setae \\
\hline Prothorax & & & & & $\mathrm{TI}$ & \\
\hline \begin{tabular}{l|l} 
pronotum \\
\end{tabular} & & V & 6 & $5+2$ & prns & Pronotal setae \\
\hline epipleuron & & $0-3$ & 2 & 2 & epls & Epipleural setae \\
\hline pleuron & & 2 & 2 & 2 & pls & Pleural setae \\
\hline pedal area & & V & 6 & 6 & $p d s$ & Pedal setae \\
\hline sternum & & 1 & 1 & 1 & sts & Sternal setae \\
\hline Meso-, Metathorax & & & & & TII, III & \\
\hline \begin{tabular}{|l|l|} 
prodorsum \\
\end{tabular} & & 1 & $1+1$ & $1+1$ & prs & Prodorsal setae \\
\hline postdorsum & & 4 & 4 & 4 & $p d s$ & Postdorsal setae \\
\hline alar area & & $1-2$ & 1 & 1 & as & Alar setae \\
\hline spiracular are & & $1-3$ & $3-9$ & $3-8$ & sS & Spiracular setae \\
\hline epipleuron & & 1 & 1 & 1 & epls & Epipleural setae \\
\hline pleuron & & 1 & 1 & $1+2$ & $p / s$ & Pleural setae \\
\hline pedal & & V & 6 & 6 & $p d s$ & Pedal setae \\
\hline sternum & & 1 & 1 & 1 & sts & Sternal setae \\
\hline Abdomen, I-VIII seg & gments & & & & Al-VIII & \\
\hline \begin{tabular}{|l|l|} 
prodorsum \\
\end{tabular} & & 1 & 1 & 1 & prs & Prodorsal setae \\
\hline postdorsum & I-VII & 5 & 5 & 5 & nds & Postdarcal setan \\
\hline & VIII & V & 2 & 2 & $p d s$ & Postdorsal setae \\
\hline spiracular & I-VII & 2 & 1 & 1 & & Sniracular cotan \\
\hline & VIII & 1 & $5-6$ & 7 & ss & Spiracular setae \\
\hline epipleuron & & 2 & 2 & 2 & epls & Epipleural setae \\
\hline pleuron & $\mid-V I I$ & 2 & 2 & 2 & 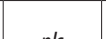 & Dhoul \\
\hline & VIII & 2 & 1 & 1 & pls & Pleural setae \\
\hline laterosternal & I-VII & 1 & 1 & 1 & & \\
\hline & VIII & 1 & 0 & 0 & Its & Laterosternal setae \\
\hline sternum & & 2 & 2 & 2 & sts & Sternal setae \\
\hline Abdomen, IX segme & & & & & AIX & \\
\hline \begin{tabular}{|l|l|} 
& disc/dorsum \\
\end{tabular} & & V & $4 / 0$ & $4 / 1$ & $d s$ & Dorsal setae \\
\hline lateral & & 2 & 0 & 1 & Is & Lateral setae \\
\hline 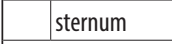 & & 2 & 2 & 2 & sts & Sternal setae \\
\hline Abdomen, $X$ segme & & & & & $A X$ & \\
\hline anal lateral & & $1-3$ & 1 & 2 & as & Anal setae \\
\hline
\end{tabular}



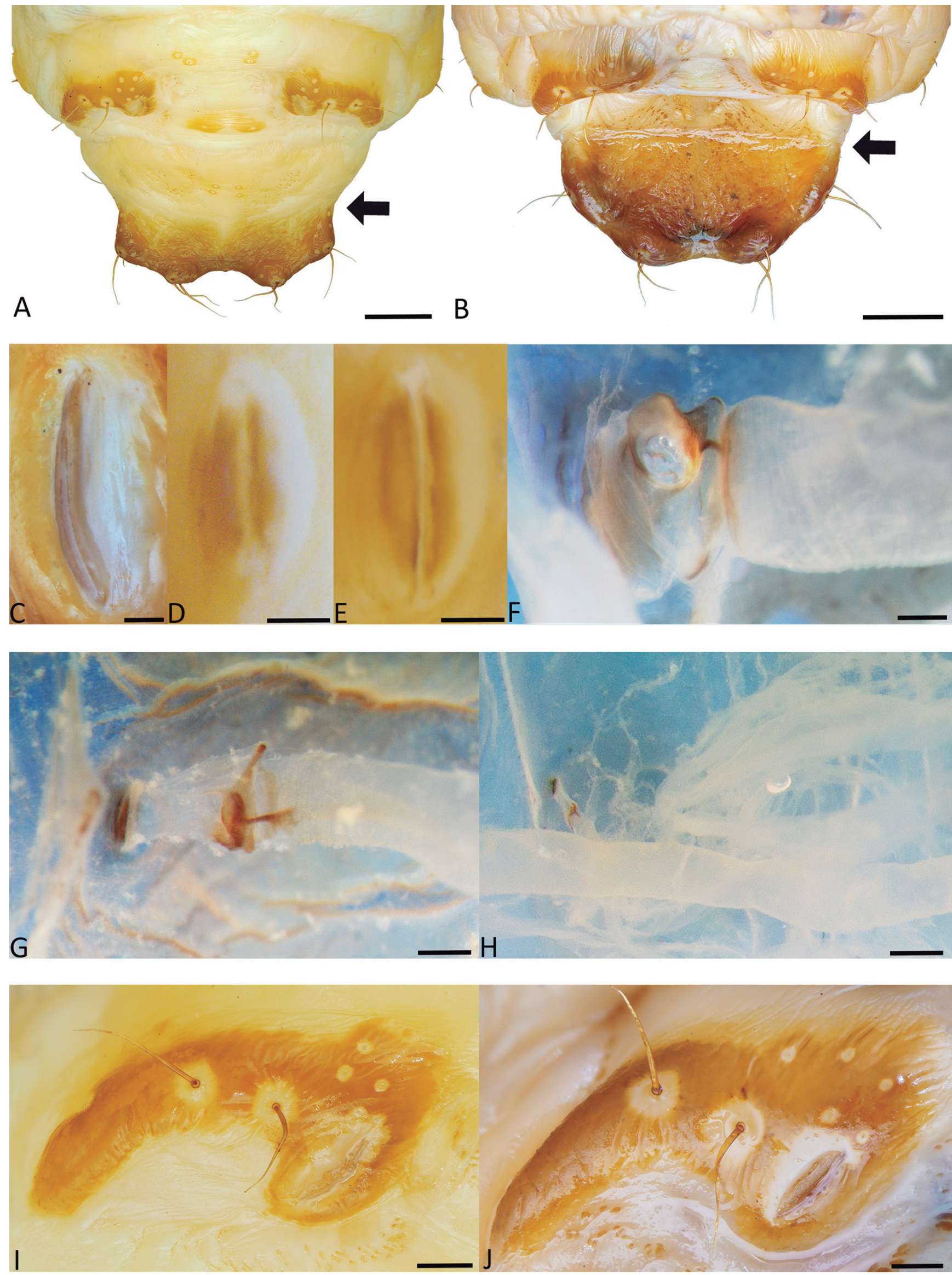

Figure 7. Larval abdominal apex showing posterior disc, dorsal: (A) Dynamis borassi (Fabricius); (B) Rhynchophorus palmarum (Linnaeus). Spiracles of D. borassi (external view, not at same scale): (C) thoracic; (D) abdominal I; (E) abdominal IV. (F) Thoracic spiracle and trachea of R. palmarum, seen from inside of body. $(G, H)$ Spiracles and tracheal system of $D$. borassi, seen from inside of body: thoracic, abdominal IV. Abdominal spiracle VIII: (I) D. borassi; (J) R. palmarum. Scale bars: $A$ and $B=2 \mathrm{~mm}, C$ and $F-H=0.2 \mathrm{~mm}, D$ and $E=0.1 \mathrm{~mm}, \mathrm{I}$ and $\mathrm{J}=0.5 \mathrm{~mm}$. 
instars with fewer setae). Hypopharynx (Fig. 5C) more densely setose laterally than anteriorly. Abdominal posterior disc (Fig. 7A) with lateral margins inwardly curved, with seta-bearing lobes defined by sinuate posterior margin (weakly so in first instar).

\section{Rhynchophorus palmarum (Linnaeus, 1758)}

Mature larva: Figs. 1D-F, 2B, D, 3A, C, 4B, E-F, I-J, 5B, D, F-I, $6 A-B, 7 B, F, J$.

\section{First instar larva: Fig. 8B.}

Maximum dimensions: $51.2 \times 23.8 \mathrm{~mm}$, head width $11.5 \mathrm{~mm}$. Chaetotaxy (see Table 1).

Frons (Fig. 2B) with three setae well developed ( $f s 3$, fs 4 and fs5). Epipharynx (Figs. 3C, 4B): ten (earlier instars) to fourteen anterolateral setae (als) on each side, posterior ones can arise near the limit with clypeus; median epipahryngeal setae 2 (mes2) slender, about as widely separated than mes1, the latter weak, unconspicuous; mesal area of epipharynx (between labral rods) with an elongate glabrous area coarsely defined by surrounding asperities; labral rods U-shaped, about as widely separated towards their proximal junction than between their distal tips. Maxillae (Figs. 5B, D, F-I): with dorsal malar setae (dms) (Figs. 5F, G) with pubescence at their bases; number of $d m s$ about 30 (earlier instars with fewer setae). Hypopharynx (Fig. 5D) densely setose in both anterior and lateral margins. Abdominal posterior disc (Fig. 7B) with lateral margins outwardly curved, with seta-bearing lobes broadly defined by slightly sinuate posterior margin.

\section{Comparative notes}

A selection of characters useful to distinguish $D$. borassi and $R$. palmarum, at larval and adult stages, is provided below (see Appendix 1 for a comparison in Spanish):
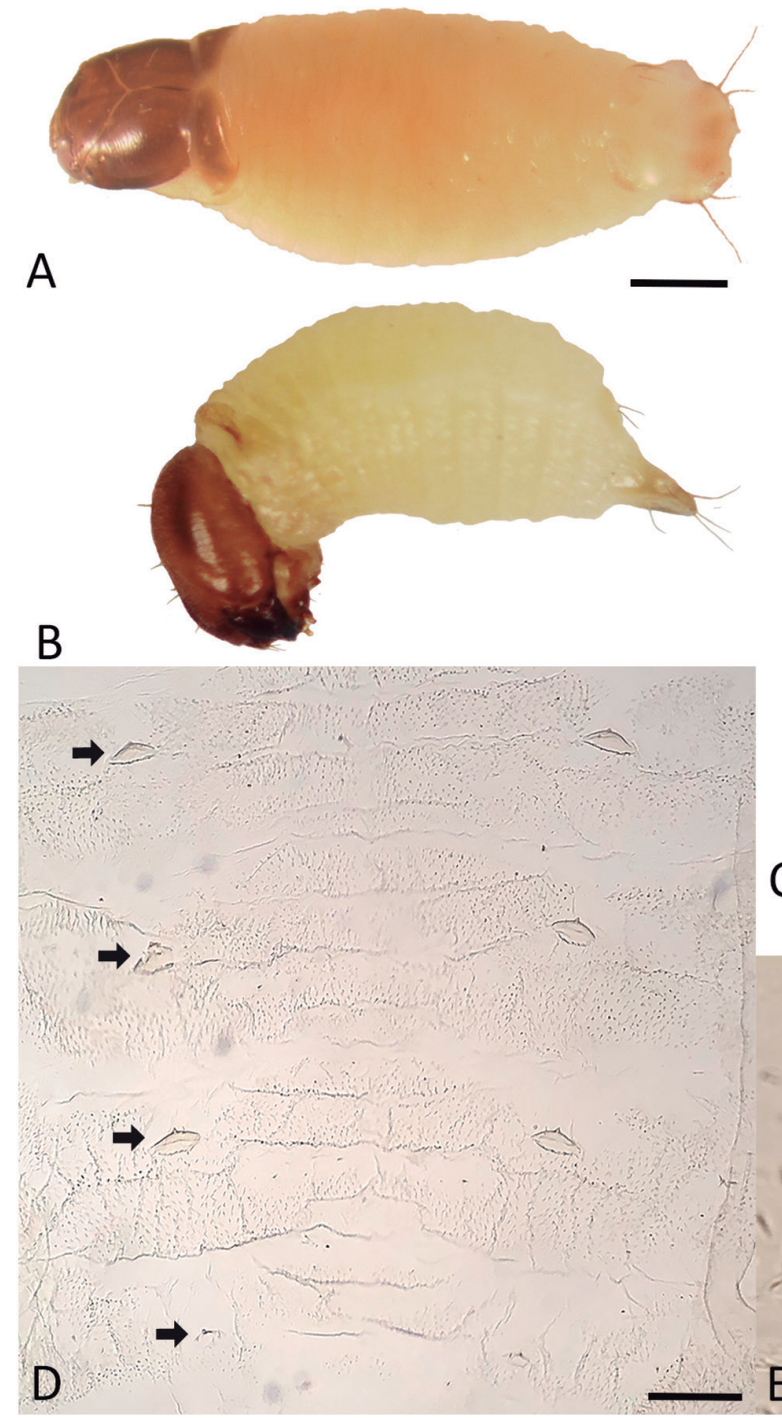

C
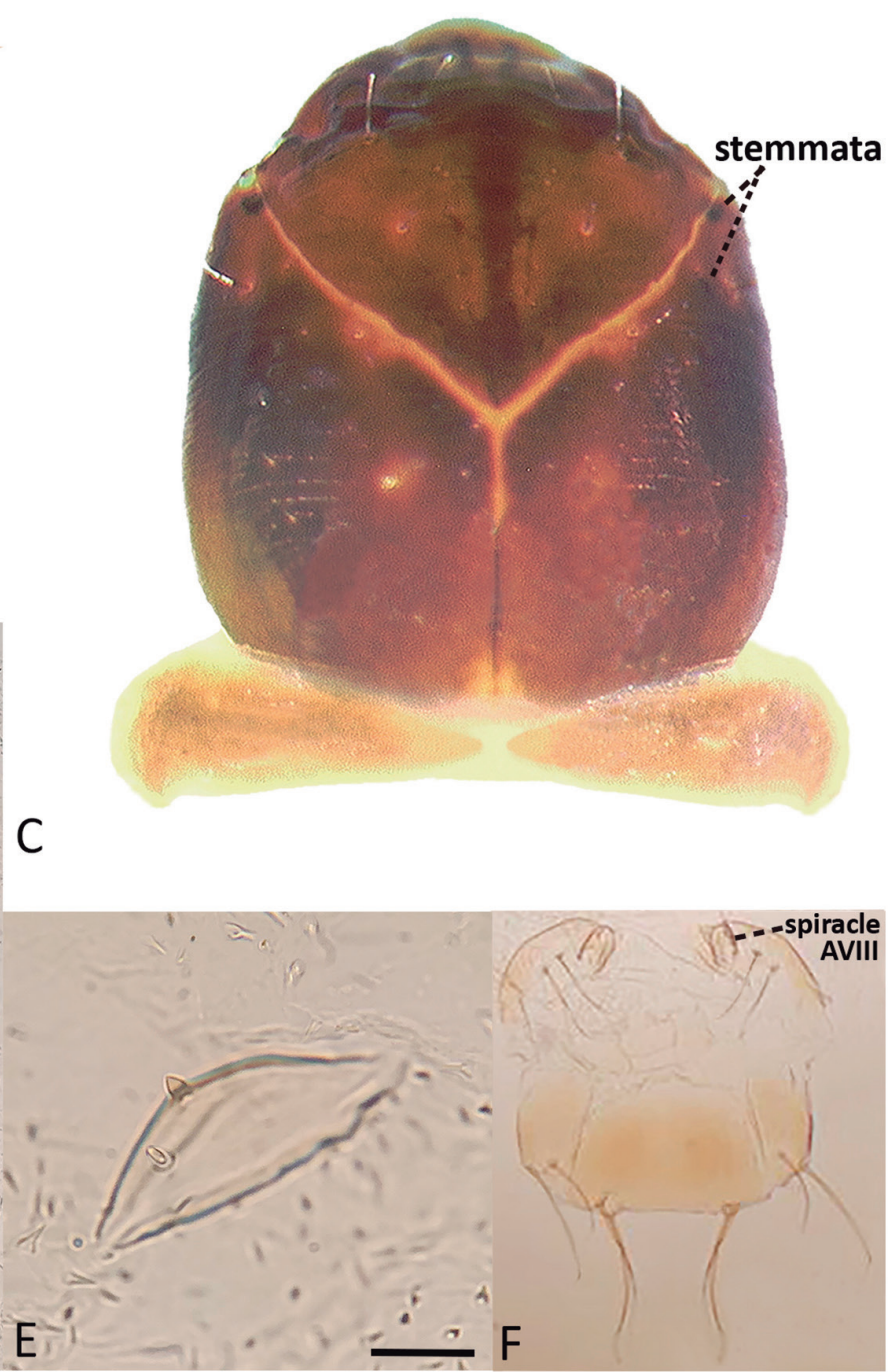

Figure 8. First instar larva. (A) Dynamis borassi (Fabricius), habitus dorsolateral; (B) Rhynchophorus palmarum (Linnaeus), habitus lateral. D. borassi: (C) head and pronotum, dorsal; (D) abdominal segments IV to VII, dorsal, showing egg bursters; (E) detail of egg burster; (F) terminal dorsal disc (abdominal tergites VIII and IX). Scale bars: $A$ and $B=0.5 \mathrm{~mm}, D=0.2 \mathrm{~mm}, E=0.03 \mathrm{~mm}$. 
Dynamis borassi: LARVAE: Frons (Fig. 2A) with two (pairs of) frontal setae well developed ( $f s 3$ and $f s 5$ ). Epipharynx (Figs. 3B, 4A) with mes 1 well developed and distinctly less widely separated than mes2, mes 2 thick; laterally with five (earlier instars) to eight als; labral rods V-shaped, less widely separated towards their proximal junction than between their distal tips. Maxillae with $\mathrm{dms}$ without pubescence at their bases (Fig. 5E). Abdominal terminal disc (Fig. 7A) with lateral margin inwardly curved. ADULTS (Figs. 10A-B, E-F, I-J): Pronotum strongly produced posteriorly and scutellum very small, about $1 / 10$ elytral length (Figs. 10E-F). Male with profemora bearing dense, erect setae on ventral side (Figs. 10A, I).

Rhynchophorus palmarum: LARVAE: Frons (Fig. 2B) with three (pairs of) frontal setae well developed ( $f s 3$, fs 4 and fs5). Epipharynx (Figs. 3C, 4B) with mes 1 very small and about as widely separated than mes2, mes 2 slender; laterally with 10 (earlier instars) to 14 als; labral rods U-shaped, about as widely separated towards their proximal junction than between their distal tips. Maxillae with $d m s$ with pubescence at their bases (Figs. 5F-G). Abdominal terminal disc (Fig. 7B) with lateral margin outwardly curved. ADULTS (Figs. 10C-D, G-H, K-L): Pronotum slightly produced posteriorly and scutellum very large,
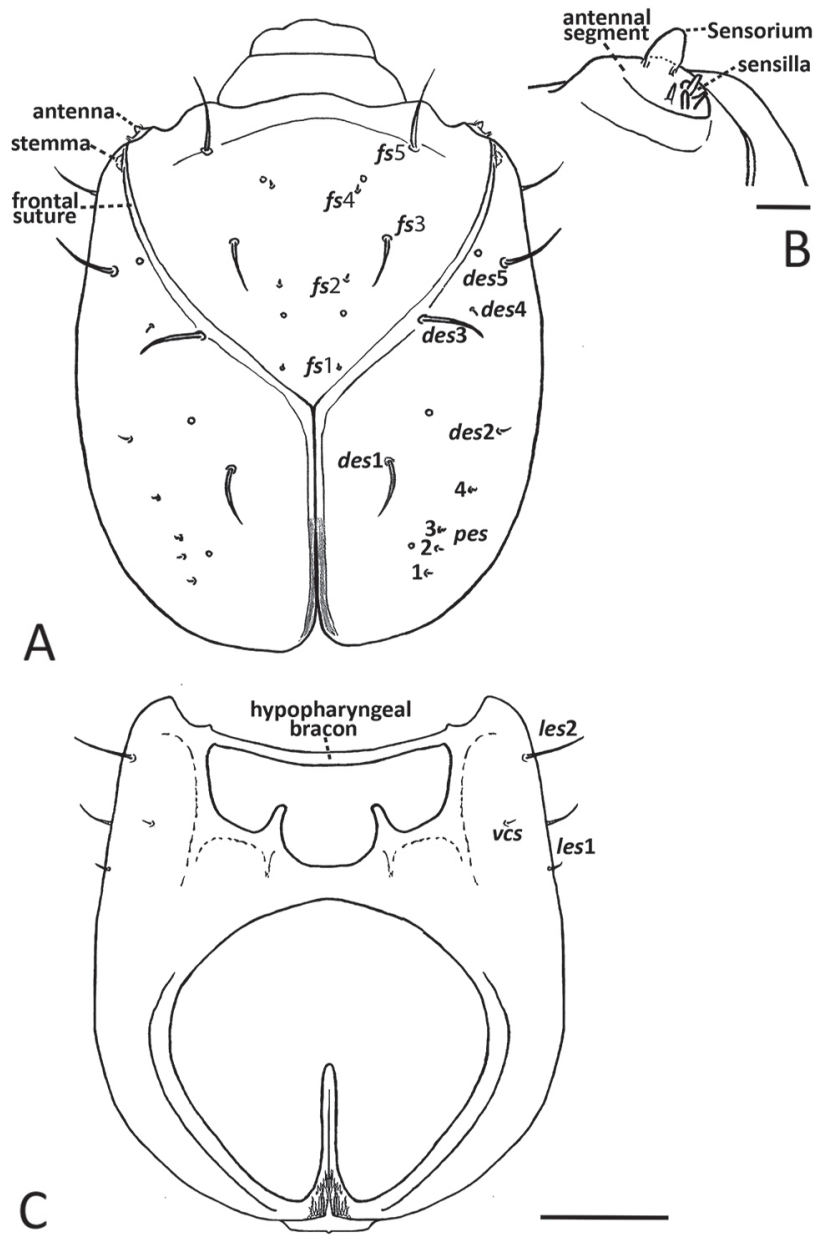

Figure 9. First instar larva of Dynamis borassi (Fabricius): (A) head capsule, dorsal; (B) detail of right antenna; (C) head capsule, ventral. Scale bars: $A$ and $C=0.2 \mathrm{~mm}, B=0.02 \mathrm{~mm}$. about $1 / 4$ elytral length (Figs. 10G-H). Male with rostrum bearing dense, erect setae on dorsal side (Figs. 10C, G).

Comments: The following additional adult characters (Wattanapongsiri, 1966; Löhr et al., 2015), in combination with those given above, distinguish $R$. palmarum from other species of Rhynchophorus: body entirely black, exceptionally reddish, interocular distance (dorsal view) $1 / 3$ or less than $1 / 3$ than the width of rostrum at base (Figs. 10G-H), rostral ventral area between the antennal scrobes rugose and with setae (Figs. 10K-L).

\section{DISCUSSION}

The larvae of Dynamis borassi and Rhynchophorus palmarum were redescribed in detail in this contribution, using modern terminology to allow comparisons with other larvae in Dryophthorinae and across Curculionidae. Few structural characters, including chaetotaxy, show clear differences between both species. In agreement with Anderson (1948) and Wattanapongsiri (1966), the most useful characters to distinguish $D$. borassi and $R$. palmarum are found in the mouthparts, particularly the epipharynx and maxillae. The observation of these features requires at least partial dissection of the head and examination under magnification, but the shape of the abdominal posterior plate, which also shows differences in both species, can be observed directly. This is advantageous to facilitate a rapid identification in the field, as required in most applied studies related to pest control. However, because differences in the abdominal plate of both species are only obvious and more distinct in older or mature larvae, it is worth to complement with other (e.g., from mouthparts) diagnostic features.

The terminology used by Wattanapongsiri (1966), to describe larval structures and chaetotaxy of Rhynchophorus and Dynamis, differs in some important aspects with the one adopted in the present work and other comparative studies (e.g., see Marvaldi, 1999; May, 1994; Chamorro \& Huang, 2019). Among the differences worth to note are those involving the "anterolateral setae of epipharynx (als)", which in Wattanapongsiri (1966) are named "lateral setae of labrum" and, as additional source of confusion, their counting is given in full and not for one side, as it is standard for description of bilateral structures. Other discrepancies with Wattanapongsiri (1966) may arise because sometimes (e.g., in mandibles, stipes) he considers and counts as setae other sensilla that are not true setae (i.e., basal socket plus "hair"). In our study, we also provided labeled figures to facilitate the determination of homology when compared with works using different terminology.

From a phylogenetic perspective, the larval characters described for both species studied are in agreement with those diagnostic and synapomorphic of subfamily Dryophthorinae, such as maxillary malae with some dorsal setae branched, the pleura subdivided, the spiracles of AVIII placed on dorsum and oriented caudally, among others (May, 1994; Marvaldi, 1999; Anderson \& Marvaldi, 

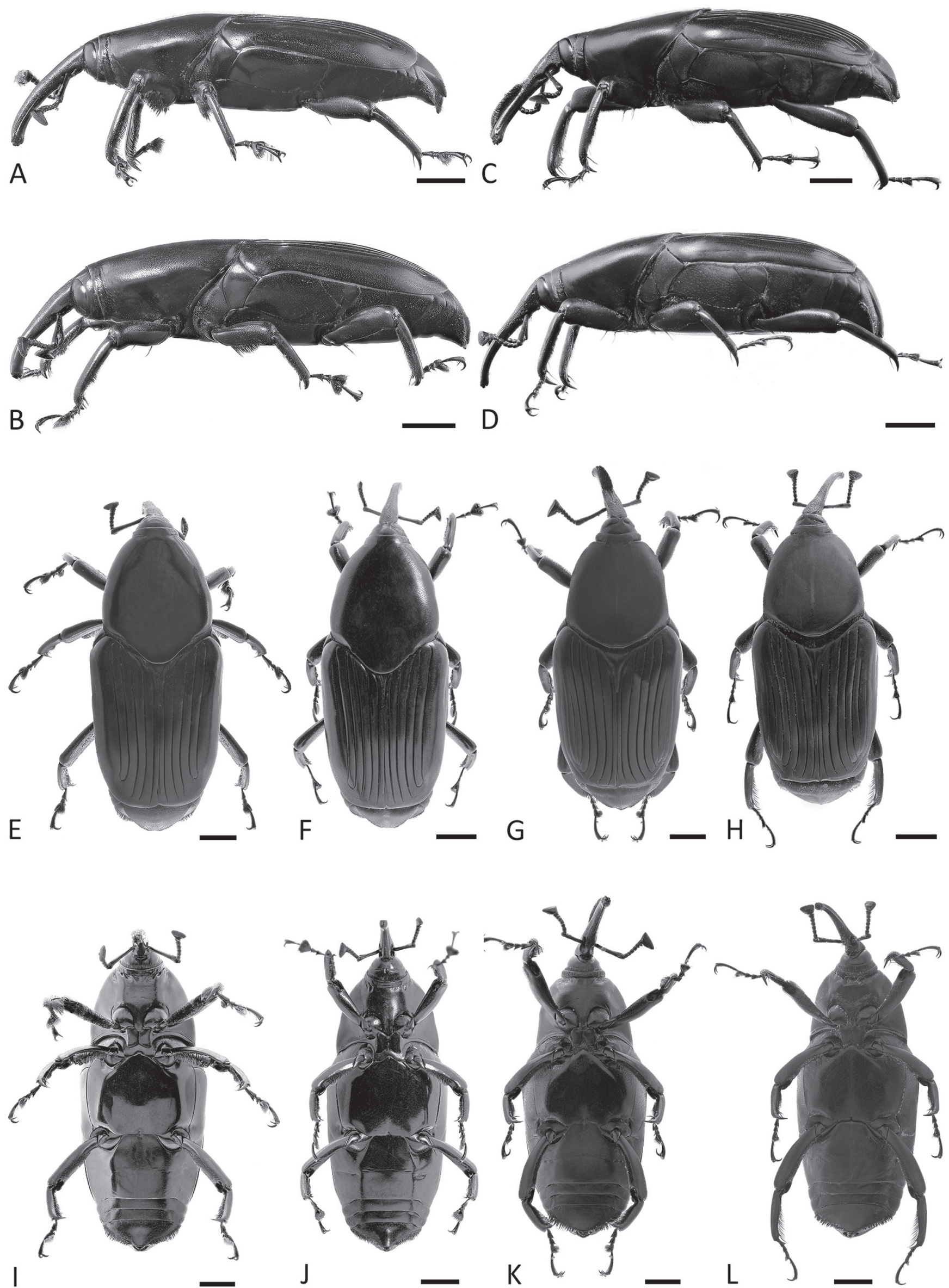

Figure 10. Adult, habitus. Dynamis borassi (Fabricius): (A) male, lateral, note sexually dimorphic ventrally setose profemora; (B) female, lateral; (E) male, dorsal; (F) female, dorsal; (I) male, ventral; (J) female, ventral. Rhynchophorus palmarum (Linnaeus): (C) male, lateral, note sexually dimorphic dorsally setose rostrum; (D) female, lateral; (G) male, dorsal; (H) female, dorsal; (K) male, ventral; (L) female, ventral. Scale bars: $5 \mathrm{~mm}$. 
2014). We also corroborate, as diagnostic of dryophthorines, that the first instar larva lacks the spiracles of abdominal segments I-VII, having only the thoracic and AVIII spiracles developed. The larvae of later instars of Dynamis and Rhynchophorus have the complete set of abdominal spiracles, and although those of Al to AVII are small, they are clearly functional (i.e., connected to tracheal system, see Fig. 7H); therefore, they are not absent as interpreted in the identification key by Chamorro (2019). The occurrence of egg-bursters in first instar larvae of Curculionoidea is less common, but also more poorly documented, than in their sister group Chrysomeloidea, where egg burster's features (e.g., position, shape) were found to be phylogenetic informative at both higher and lower taxonomic levels (Cox, 1988). In Dryophthorinae, egg bursters were known to occur in first instar larvae of genus Sitophilus of subtribe Litosomina, and in the present contribution, we report their occurrence in representatives of Rhynchophorina.

\section{ACKNOWLEDGMENTS}

We are grateful to the different communities and secretaries of agriculture of the municipalities and departments visited, who facilitated the work. We also thank Inge Armbrecht and James Montoya, for their management of the Colciencias's project; Jackelinae Gaviria and Claudia Marcela Cuellar, for providing specimens; and Diana Marcela Urcuqui, Francisco Lopez Machado and Juan Felipe Ortega, for their technical help with photography at Universidad del Valle. This paper is dedicated in homage to Dr. Cleide Costa, in recognition of her contributions to the knowledge on immature stages and biology of Neotropical beetles.

\section{FUNDING}

This work was supported by Colciencias (Project Code FP44842-428-2017 and Doctoral Grant 757-2016 to AAVO) and by the Biology Graduate program of the Universidad del Valle, "Corporación colombiana de investigación agropecuaria (Agrosavia)". AEM's research and AAVO's internship in her lab were supported by the National Agency of Promotion of Science of Argentina (ANPCyT, grant PICT 2016-2798), and by the National University of La Plata (UNLP, grant 11/N852).

\section{REFERENCES}

Agronet (Red de Información y Comunicación del Sector Agropecuario Colombiano). 2016. Estadística para el sector agrícola. Base Agrícola EVA 2007-2016. Available at: http://www.agronet.gov.co/estadistica/ Paginas/default.aspx. Access in: 03/2019.

Anderson, W.H. 1948. Larvae of some genera of Calendrinae (= Rhynchophorinae) and Stromboscerinae (Coleoptera: Curculionidae). Annals of the Entomological Society of America, 41(4): 413-437.
Anderson, R.S. \& Marvaldi, A.E. 2014. 3.7.3 Dryophthorinae Schoenherr, 1825. In: Leschen, R.A.B. \& Beutel, R.G. (Eds.). Coleoptera, Beetles. Vol. 3 : Morphology and systematics: Phytophaga. Berlin, Walter de Gruyter. p. 477-483. (Handbook of Zoology: Arthropoda: Insecta)

Chamorro, M.L. 2019. An illustrated synoptic key and comparative morphology of the larvae of Dryophthorinae (Coleoptera, Curculionidae) genera with emphasis on the mouthparts. Diversity, 11(1): 1-96.

Chamorro, M.L. \& Huang, C. 2019. Descriptions of the Immature Stages of Poteriophorus Schoenherr, 1838 (Coleoptera: Curculionidae: Dryophthorinae): Larva, Pupa, and Biology of Poteriophorus uhlemanni (Schultze, 1922) Discovered through Dawu Traditional Ecological Knowledge. The Coleopterists Bulletin, 73(2): 283-299.

Cotton, R.T. 1924. A contribution toward the classification of the weevil larvae of the subfamily Calendrinae, occurring in North America. Proceedings of the United States National Museum, 66(5): 1-11.

Couturier, G.; Padhila de Oliveria, M. \& Beserra, P. 2000. Besouros nocivos à bacabeira: Dynamis borassi e Foveolus aterpes. EMBRAPA Comunicação Técnica, 19: 1-5.

Cox, M. 1988. Egg bursters in the Chrysomelidae, with a review of their occurrence in the Chrysomeloidea and Curculionoidea (Coleoptera). Systematic Entomology, 13: 393-432.

Cuellar Palacios, C.M. 2019. Ciclo de vida de Dynamis borassi (Coleoptera: Dryophthoridae) en condiciones de laboratorio. In: Congreso SOCOLEN, $46^{\circ}$ Resumos. Cali, Colombia, Sociedad Colombiana de Entomologia/ Universidad del Valle.

Giblin-Davis, R.M.; Faleiro, J.R.; Jacas, J.A.; Peña, J.E. \& Vidyasagar, P.S.P.V. 2013. Biology and management of the red palm weevil, Rhynchophorus ferrugineus. In: Peña, J.E. (Ed.). Potential invasive pests of agricultural crops. London, CABI Invasives Series. p. 1-34.

Instituto Colombiano Agropecuario (ICA). 2015. Resolución 1786 de 2015. Available at: http://www.icbf.gov.co/cargues/avance/docs/resolucion ica 1786 2015.htm. Access in: 09/2016.

Löhr, B.; Vásquez-Ordóñez, A.A. \& Becerra Lopez-Lavalle, L.A. 2015. Rhynchophorus palmarum in Disguise: Undescribed Polymorphism in the "Black" Palm Weevil. PloS one, 10(12): p.e0143210.

Löhr, B.L. 2016. Manual de cría del picudo negro de las palmas, Rhynchophorus palmarum. Mosquera, Colombia, Corporación Colombiana de Investigación Agropecuaria (Corpoica).

Marvaldi, A.E. 1999. Morfología larval en Curculionidae (Insecta: Coleoptera). Acta Zoológica Lilloana, 45(1): 7-24.

May, B.M. 1994. An Introduction to the Immature Stages of Australian Curculionoidea. In: Zimmerman, E.C. \& May, B.M. (Eds.). Australian weevils (Coleoptera: Curculionoidea). Brentidae, Eurhynchidae, Apionidae and a chapter on immature stages. Melbourne, CSIRO Editorial Services. v. 2, p. 366-726.

Oberprieler, R.G.; Andreson, R.S. \& Marvaldi, A.E. 2014. Curculionidea Latreille 1802. Introduction, phylogeny. In: Leschen, R.A.B. \& Beutel, R.G. (Eds.). Coleoptera, Beetles. Vol. 3: Morphology and systematics: Phytophaga. Berlin, Walter de Gruyter. p. 285-300. (Handbook of Zoology, Arthropoda: Insecta)

Pardo-Locarno, L.C.; Vallecilla Camacho, H. \& Caicedo, R. 2016. Avances en el diagnóstico fitosanitario del cultivo de chontaduro en la zona rural de Buenaventura, Valle. Revista Científica Sabia, 1(3): 47-61.

Wattanapongsiri, A. 1966. A revision of the genera Rhynchophorus and Dynamis (Coleoptera: Curculionidae). Oregon, Oregon State University. 


\section{APPENDIX 1}

\section{Caracteres diagnósticos para la identificación morfológica de larvas y adultos de Dynamis borassi y Rhynchophorus palmarum.}

\begin{tabular}{|c|c|c|}
\hline & Dynamis borassi & Rhynchophorus palmarum \\
\hline \multicolumn{3}{|l|}{ LARVAS } \\
\hline $\begin{array}{l}\text { Cabeza: Cantidad de setas frontales (a cada lado) bien } \\
\text { desarrolladas }\end{array}$ & Dos (Fig. 2A) & Tres (Fig. 2B) \\
\hline Epifaringe: Setas epifaringeales medias (mes) & $\begin{array}{l}\text { Setas del primer par (mes1) bien distinguibles, separadas entre sí } \\
\text { por menor distancia que entre las del segundo par (mes2), éstas } \\
\text { robustas (Figs. 3B, 4A) }\end{array}$ & $\begin{array}{l}\text { Setas del primer par (mes1) muy débiles, pequeñas, separadas } \\
\text { entre sí por igual distancia que las del segundo par (mes2), éstas } \\
\text { delgadas (Figs. 3C, 4B) }\end{array}$ \\
\hline Epifaringe: Cantidad de setas anterodorsales (als) a cada lado & Cinco a ocho (Figs. 3B, 4A) & 10 a 14 (Figs. 3C, 4B) \\
\hline Epifaringe: Forma de las varillas labrales & $\begin{array}{l}\text { Parecida a una "V", las varillas más separadas hacia el ápice que } \\
\text { cerca de su base (Figs. 3B, 4A) }\end{array}$ & $\begin{array}{l}\text { Parecida a una "U", las varillas aproximadamente tan separadas } \\
\text { cerca de su base como distalmente (Figs. 3C, 4B) }\end{array}$ \\
\hline Maxilas: Setas dorsales de la mala ( $m d s$ ) & Sin pubescencia en su base (Fig. 5E) & Con pubescencia en su base (Figs. 5F-G) \\
\hline Abdomen: Margen lateral del disco terminal & Curvado hacia adentro (Fig. 7A) & Curvado hacia afuera (Fig. 7B) \\
\hline \multicolumn{3}{|l|}{ ADULTOS } \\
\hline Base del pronoto & Marcadamente extendida hacia atrás (Figs. 10E-F) & Suavemente extendida hacia atrás (Figs. 10G-H) \\
\hline Escutelo & Muy pequeño, alrededor de 1/10 el largo de los élitros (Figs. 10E-F) & Muy grande, alrededor de $1 / 4$ el largo de los élitros (Figs. 10G-H) \\
\hline Dimorfismo sexual & $\begin{array}{l}\text { Macho con fémures anteriores densamente setosos en su cara } \\
\text { ventral (Figs. 10A, I) }\end{array}$ & $\begin{array}{l}\text { Macho con rostro provisto de setas densas, erectas, en su cara } \\
\text { dorsal (Figs. 10C, G) }\end{array}$ \\
\hline
\end{tabular}

Nota: Los siguientes caracteres adicionales del adulto (Wattanapongsiri, 1966; Löhr et al., 2015), en combinación con los anteriores, distinguen a R. palmarum de otras especies de Rhynchophorus: cuerpo completamente negro, excepcionalmente rojizo, distancia entre los ojos (vista dorsal) 1/3 o menos de 1 1 3 que el ancho del rostro en la base (Figs. 10G-H), área ventral del rostro entre las escrobas antenales rugosa y con setas (Figs. 10K-L) 